\title{
Seed treatment and its impact on wheat crop yield potential ${ }^{1}$
}

\author{
Joice Aline Freiberg ${ }^{2 *}$, Marcos Paulo Ludwig ${ }^{3}$, \\ Suemar Alexandre Gonçalves Avelar ${ }^{4}$, Eduardo Girotto ${ }^{3}$
}

\begin{abstract}
In the sowing process, the technique of seed treatment may assist in maintaining crop yield potential. This present study aimed to assess how wheat seed treatment with two different sources of micronutrients, combined with fungicide + insecticide protective treatment and coating with liquid polymer, may impact its vegetative development and grain production. Wheat seeds of cultivar Tec Vigore were subjected to three different treatments using micronutrient containing zinc: no micronutrient, micronutrient 1 ( $1 \% \mathrm{Mn}, 0.1 \% \mathrm{Mo}, 10 \% \mathrm{Zn})$; micronutrient $2(0.3 \% \mathrm{~B}, 0.3 \% \mathrm{Co} ; 3 \% \mathrm{Zn})$, where micronutrient treatments were combined with different protective treatments used for seed treatment: untreated seeds, polymer (Color seed He), fungicide (Vitavax ${ }^{\circledR}$ Thiram 200 SC) + insecticide (Cruiser ${ }^{\circledR} 350$ FS) and combination of polymer + fungicide + insecticide. We assessed parameters related to crop development, such as seedling emergence, dry matter of root and shoot, tillers, and for physiological maturity, we assessed grain yield and hectoliter weight. Seed treatment with micronutrients, polymer, fungicide + insecticide and combinations thereof does not reduce emergence and may increase seedling stand, but without influencing wheat grain yield.
\end{abstract}

Index terms: fungicide, insecticide, micronutrient, polymer.

\section{Tratamento de sementes e sua influência no potencial produtivo da cultura do trigo}

\begin{abstract}
RESUMO - No processo de semeadura, a técnica do tratamento de sementes pode auxiliar na manutenção do potencial produtivo. Objetivou-se com esse trabalho avaliar a influência do tratamento de sementes de trigo com duas diferentes fontes de micronutrientes, combinadas aos tratamentos protetores fungicida + inseticida e recobrimento com polímero líquido, no desenvolvimento vegetativo e na produção de grãos. As sementes de trigo, cultivar Tec Vigore, foram submetidas a três diferentes tratamentos utilizando micronutrientes contendo zinco: sem micronutriente, micronutriente 1 ( $1 \% \mathrm{Mn} ; 0,1 \% \mathrm{Mo}$; $10 \% \mathrm{Zn})$; micronutriente $2(0,3 \% \mathrm{~B} ; 0,3 \% \mathrm{Co} ; 3 \% \mathrm{Zn})$, sendo os tratamentos micronutrientes combinados com diferentes tratamentos protetores utilizados no tratamento de sementes: sementes sem tratamento, polímero (Color seed He), fungicida (Vitavax ${ }^{\circledR}$ Thiram 200 SC) + inseticida (Cruiser ${ }^{\circledR} 350$ FS) e polímero + fungicida + inseticida. Foram avaliados parâmetros relacionados ao desenvolvimento da cultura como emergência de plântulas, massa seca de raiz e parte aérea, perfilhos, e na maturação fisiológica avaliou-se o rendimento de grãos e o peso do hectolitro. O tratamento de sementes com micronutrientes, polímero, fungicida + inseticida e suas combinações não reduz a emergência e pode aumentar o estande de plântulas, mas sem efeitos na produtividade de grãos de trigo.
\end{abstract}

Termos para indexação: fungicida, inseticida, micronutriente, polímero.

\section{Introduction}

Wheat is a significant part of Brazilian population diet. The great interest in increasing the productivity

\footnotetext{
${ }^{1}$ Submitted on 03/29/2017. Accepted for publication on 08/14/2017. ${ }^{2}$ Departamento de Solos, UFSM, Caixa Postal 5082, 97105-100 - Santa Maria, RS, Brasil.

${ }^{3}$ Instituto Federal de Educação, Ciência e Tecnologia do Rio Grande do Sul, Caixa Postal 121, 98200-000 - Ibirubá, RS, Brasil.
}

and competitiveness of Brazilian wheat is justified by the socioeconomic importance of wheat culture for the sustainability of agricultural properties and the pursuit for self-sufficiency in production (Franceschi et al., 2009).

${ }^{4}$ Departamento de Horticultura, Cornell University, 14456 - Geneva, New York, EUA.

*Corresponding author <joice.freiberg@hotmail.com> 
To achieve high agricultural yields it is paramount to understand factors such as management of crop and environment (Mertz et al., 2009). In the sowing process, the use of seeds with high physiological and sanitary quality is essential for the adequate establishment of the plant. Thus, the use of pesticides through seed treatment may allow greater initial development of crops by providing good plant defense conditions (Castro et al., 2008) against insects (Dan et al., 2012) and fungi (Garcia Júnior et al., 2008). In addition, the use of efficient active ingredients can reduce post-emergence applications of fungicides (Picinini and Fernandes, 2003) and insecticides, reducing production costs and the negative impact on the environment.

Just as fungicides and insecticides, polymers and micronutrients can improve the agronomic performance of crops through seed treatment. The use of polymers improves seed adhesion, distribution, and coloration without impairing its quality and performance (Bays et al., 2007). It can also reduce leaching of products and improve the sowing ability of seeds (Avelar et al., 2012). With regard to micronutrients, Prado et al. (2007a) found that zinc seed treatment favored initial seedling growth and dry matter production in wheat, as well as Tavares et al. (2013b) in wheat seeds treated with micronutrients.

Many studies have discussed the impact of seed treatment on the physiological quality of seeds and on the initial development of plants, but not much research have focused on grain yield and the association of micronutrients, polymer, fungicide and insecticide. By favoring an adequate initial development of plants, the treatment of seeds can allow better yields. While studying the coating of seeds with zinc, Tunes et al. (2012) have found increased number of grains per spikelet and grain weight; and Tavares et al. (2013b) obtained an increase in grain yield from seeds treated with zinc, boron and molybdenum. However, Brzezinski et al. (2015) verified that the treatment of seeds with fungicides and insecticides did not impact soybean crop yield.

Therefore, the objective of this work was to evaluate how seed treatment with two different sources of micronutrients, combined with fungicide + insecticide and liquid polymer coating might affect the vegetative development and grain yield of wheat.

\section{Material and Methods}

The experiment was conducted during the 2012 and 2013 crops, in the experimental area of the Federal Institute of Education, Science and Technology of the state of Rio Grande do Sul - IFRS, Campus Ibirubá, RS, Brazil. Seeds were submitted to three different treatments using micronutrients containing zinc: no micronutrient, micronutrient 1 ( $1 \% \mathrm{Mn}, 0.1 \% \mathrm{Mo}, 10 \% \mathrm{Zn})$; micronutrient $2(0.3 \% \mathrm{~B}$; $0.3 \% \mathrm{Co} ; 3 \% \mathrm{Zn}$ ), where micronutrient treatments were combined with different protective treatments used in seed treatment: untreated seeds, polymer (Color seed $\mathrm{He}$ ), fungicide $\left(\right.$ Vitavax $^{\circledR}$ Thiram 200 SC) + insecticide (Cruiser ${ }^{\circledR} 350$ FS) and combination of polymer + fungicide + insecticide.

Wheat seeds of cultivar Tec Vigore used in the sowing of the 2012 crop were produced in the 2011/2011 crop. They belonged to genetic category and presented $99 \%$ of germination and $100 \%$ of purity. In the 2013 crop, the seeds of this cultivar, coming from the $2012 / 2012$ crop, belonged to genetic category and presented $80 \%$ of germination and $93 \%$ of purity, respectively.

The treatments were applied by preparing the syrup according to manufacturer recommendations. Doses of 1.5 $\mathrm{mL} . \mathrm{kg}^{-1} ; 1.2 \mathrm{~mL} . \mathrm{kg}^{-1} ; 2.5 \mathrm{~mL} . \mathrm{kg}^{-1}$ and $1.0 \mathrm{~mL} . \mathrm{kg}^{-1}$ were used respectively for micronutrients, polymer, fungicide, and insecticide. Together with the products, water was added up to the maximum volume of $8 \mathrm{~mL} \cdot \mathrm{kg}^{-1}$. The mixture of the products with $0.5 \mathrm{~kg}$ of seed was carried out in plastic bags with volumetric capacity of $2 \mathrm{~kg}$, and the seeds were shaken until completely recoated. The experimental design used was in randomized blocks, in a $3 \times 4$ factorial scheme (micronutrients $\mathrm{x}$ protective treatments), totaling twelve treatments, with four replications per treatment.

The experiment was carried out in June 2012 and 2013, through direct sowing, after the soybean culture. The plots consisted of 20 rows of five meters in length, spaced at 0.17 meters.

The management of the crop, for fertilization and phytosanitary control, followed the recommendations of the Commission of Chemistry and Soil Fertility - RS/SC (2004) and the technical information for the control of weeds, diseases and pests in wheat crops 2012 and 2013 (EMBRAPA, 2011, IAPAR, 2012).

In the 2012 and 2013 crops, parameters related to crop development and grain yield were assessed. Seedling emergence was determined at 14 and 21 days after sowing (DAS), and plant population at $41 \mathrm{DAS}$. In order to do so, the number of seedlings/plants emerged in a linear meter was counted, from the average of two linear meters in each replication.

At seven DAS and 82 DAS, seedlings and wheat plants were collected, respectively, for dry shoot mass and seedlings were collected for root dry mass at seven DAS. These remained at $65^{\circ} \mathrm{C}$ in drying oven until constant mass that was expressed in grams.plant ${ }^{-1}$. Plant height was determined by gauging the length of 15 plants from the first node at 41DAS. At 41 and 62 DAS the number of tillers per plant was determined. 
When reaching the physiological maturity of wheat crop we proceeded with the harvesting of six central rows consisting of three meters. The grain yield $\left(\mathrm{kg} \cdot \mathrm{ha}^{-1}\right)$ was obtained weighing and adjusting the humidity to $13 \%$. We determined hectoliter weight $\left(\mathrm{kg} \cdot \mathrm{hl}^{-1}\right)$ by using a container of a particular volume, followed by weighing and processing the volume in $\mathrm{kg} \cdot \mathrm{hl}^{-1}$ according to the official table for cereal hectoliter weight.

The data were submitted to analysis of variance and test of hypotheses to verify the significance of the effect of treatments and interactions. The Scott-Knott test at 5\% significance was used to compare means. The analyzes were carried out in program R, using the function "ea2" of the easy anova package (Arnhold, 2013).

\section{Results and Discussion}

The factors micronutrient and protective treatments and their interactions were not significant for seedling emergence at 14 DAS in the 2012 crop (Table 1). At 21 DAS, there was effect of micronutrients and protective treatments. Seeds treated with micronutrient 2 obtained a larger plant stand in relation to the seeds treated with micronutrient 1 . The protective treatments polymer, fungicide + insecticide and polymer + fungicide + insecticide significantly reduced plant stand in relation to the untreated seeds. In soybean, Conceição et al. (2014) found that seeds treated with fungicide, insecticide and polymer showed higher plant establishment in the field, contrary to the results found in this study. However, Pereira et al. (2005), when evaluating the action of two polymers associated with fungicide and insecticide treatment, did not find significant differences in the emergence speed of corn seedlings. These authors emphasize that the use of polymers can reduce this parameter due to the film, which restricts the oxygenation of the seeds. At 41 days, no significant effect of micronutrient use and protective treatments was observed in the plant population.

In the 2013 crop, there was a significant effect between micronutrients and protective treatments (Table 2). At 14 DAS $(p=0.001)$, lower performance was observed in untreated seeds without micronutrients, evidencing the importance of seed treatment in adequate seedlings establishment. At 21 DAS $(p=0.0016)$ it was observed that the seeds treated with polymer had a superior performance in relation to the micronutrients, especially to the micronutrient 2 . However, when the fungicide + insecticide associated to micronutrients was used, the emergence of seedlings and the plant population $(p<0.001)$ were favored. Few studies address different product associations in wheat seeds, however, in the soybean

Table 1. Seedling emergence at 14 and 21 DAS and plant population in the wheat culture submitted to seeds treatment with micronutrients and protective treatments (fungicide + insecticide and/or polymer), in 2012 .

\begin{tabular}{cccc}
\hline \multirow{2}{*}{ Treatments } & \multicolumn{2}{c}{$\begin{array}{c}\text { Emergence of } \\
\text { seedlings }\end{array}$} & $\begin{array}{c}\text { Plant } \\
\text { population }\end{array}$ \\
\cline { 2 - 4 } & \multicolumn{3}{c}{ Micronutrients } \\
\hline No Micronutrient & $30 \mathrm{a}$ & $78 \mathrm{a}$ & $88 \mathrm{a}$ \\
Micro 1 & $37 \mathrm{a}$ & $73 \mathrm{~b}$ & $83 \mathrm{a}$ \\
Micro 2 & $40 \mathrm{a}$ & $80 \mathrm{a}$ & $84 \mathrm{a}$ \\
\hline \multicolumn{4}{c}{ Protective Treatments } \\
\hline Untreated & $36 \mathrm{a}$ & $82 \mathrm{a}$ & $88 \mathrm{a}$ \\
Polymer & $33 \mathrm{a}$ & $75 \mathrm{~b}$ & $85 \mathrm{a}$ \\
Fungicide + Insecticide & $40 \mathrm{a}$ & $77 \mathrm{~b}$ & $87 \mathrm{a}$ \\
Polymer + Fungicide + Insecticide & $33 \mathrm{a}$ & $73 \mathrm{~b}$ & $81 \mathrm{a}$ \\
\hline CV $(\%)$ & 36.4 & 9.6 & 12.4 \\
\hline
\end{tabular}

The averages followed by the same letter in the column do not differ among themselves by Scott-Knott test $(\mathrm{p} \leq 0.05)$.

Table 2. Seedling emergence at 14 and 21 DAS and plant population in the wheat culture submitted to seeds treatment with micronutrients and protective treatments (fungicide + insecticide and/or polymer), in 2013.

\begin{tabular}{|c|c|c|c|c|c|c|c|c|c|}
\hline \multirow{3}{*}{$\begin{array}{l}\text { Protective } \\
\text { treatments }\end{array}$} & \multicolumn{3}{|c|}{$\begin{array}{c}\text { Seedling emergence } \\
14 \text { DAS }\end{array}$} & \multirow{2}{*}{\multicolumn{3}{|c|}{$\begin{array}{c}\text { Seedling emergence } \\
21 \text { DAS } \\
\text { Micronutrients }\end{array}$}} & \multicolumn{3}{|c|}{ Plant population } \\
\hline & & & & & & & & & \\
\hline & N/M* & M1 & M2 & $\mathrm{N} / \mathrm{M}$ & M1 & M2 & $\mathrm{N} / \mathrm{M}$ & M1 & M2 \\
\hline $\mathrm{NT}^{*}$ & $52 \mathrm{Bb}$ & $95 \mathrm{Aa}$ & $82 \mathrm{Aa}$ & $53 \mathrm{Bb}$ & $97 \mathrm{Aa}$ & $85 \mathrm{Aa}$ & $57 \mathrm{Bb}$ & $92 \mathrm{Aa}$ & $79 \mathrm{Aa}$ \\
\hline $\mathrm{P}$ & $98 \mathrm{Aa}$ & $83 \mathrm{Ba}$ & $69 \mathrm{Ba}$ & $99 \mathrm{Aa}$ & $83 \mathrm{Ba}$ & $70 \mathrm{Ba}$ & $98 \mathrm{Aa}$ & $77 \mathrm{Ba}$ & $65 \mathrm{Bb}$ \\
\hline $\mathrm{F}+\mathrm{I}$ & $68 \mathrm{Bb}$ & $95 \mathrm{Aa}$ & $97 \mathrm{Aa}$ & $72 \mathrm{Bb}$ & $96 \mathrm{Aa}$ & $100 \mathrm{Aa}$ & $65 \mathrm{Bb}$ & $90 \mathrm{Aa}$ & $96 \mathrm{Aa}$ \\
\hline $\mathrm{P}+\mathrm{F}+\mathrm{I}$ & $93 \mathrm{Aa}$ & $95 \mathrm{Aa}$ & $87 \mathrm{Aa}$ & $96 \mathrm{Aa}$ & $97 \mathrm{Aa}$ & $88 \mathrm{Aa}$ & $91 \mathrm{Aa}$ & $98 \mathrm{Aa}$ & $84 \mathrm{Aa}$ \\
\hline CV (\%) & \multicolumn{3}{|c|}{17.2} & \multicolumn{3}{|c|}{17.4} & \multicolumn{3}{|c|}{16.7} \\
\hline
\end{tabular}

*Untreated (NT), polymer (P), fungicide (F), insecticide (I), no micronutrients (N/M), micronutrients $(\mathrm{M})$.

The averages followed by the same letter, uppercase in the line and lowercase in the column, do not differ among themselves by Scott-Knott test ( $\mathrm{p} \leq 0.05$ ). 
Table 3. Shoot dry mass and root dry mass at seven DAS in the wheat culture submitted to seeds treatment with micronutrients and protective treatments (fungicide + insecticide and/or polymer), in 2012.

\begin{tabular}{|c|c|c|c|c|c|c|}
\hline \multirow{3}{*}{ Protective treatments } & \multicolumn{3}{|c|}{ Shoot dry mass (g.plant ${ }^{-1}$ ) } & \multicolumn{3}{|c|}{ Root dry mass (g.plant ${ }^{-1}$ ) } \\
\hline & \multicolumn{6}{|c|}{ Micronutrients } \\
\hline & $\mathrm{N} / \mathrm{M}$ & M1 & M2 & $\mathrm{N} / \mathrm{M}$ & M1 & M2 \\
\hline $\mathrm{NT}^{*}$ & $0.308 \mathrm{Aa}$ & $0.293 \mathrm{Aa}$ & $0.260 \mathrm{Aa}$ & $0.100 \mathrm{Aa}$ & $0.100 \mathrm{Aa}$ & $0.100 \mathrm{Aa}$ \\
\hline $\mathrm{P}$ & $0.263 \mathrm{Aa}$ & $0.218 \mathrm{Bb}$ & $0.273 \mathrm{Aa}$ & $0.087 \mathrm{Aa}$ & $0.088 \mathrm{Aa}$ & $0.105 \mathrm{Aa}$ \\
\hline $\mathrm{F}+\mathrm{I}$ & $0.278 \mathrm{Aa}$ & $0.300 \mathrm{Aa}$ & $0.235 \mathrm{Ba}$ & $0.098 \mathrm{Aa}$ & $0.100 \mathrm{Aa}$ & $0.073 \mathrm{Bb}$ \\
\hline $\mathrm{P}+\mathrm{F}+\mathrm{I}$ & $0.285 \mathrm{Aa}$ & $0.243 \mathrm{Ab}$ & $0.268 \mathrm{Aa}$ & $0.110 \mathrm{Aa}$ & $0.085 \mathrm{Aa}$ & $0.100 \mathrm{Aa}$ \\
\hline $\mathrm{CV}(\%)$ & \multicolumn{3}{|c|}{12.6} & \multicolumn{3}{|c|}{16.0} \\
\hline
\end{tabular}

*Untreated (NT), polymer (P), fungicide (F), insecticide (I), no micronutrients (N/M), micronutrients (M).

The averages followed by the same letter, uppercase in the line and lowercase in the column, do not differ among themselves by Scott-Knott test ( $\mathrm{p} \leq 0.05$ ).

crop, Avelar et al. (2015) found that the use of liquid polymer with micronutrients containing Co and Mo did not affect the seedlings emergence.

The results of shoot dry mass of wheat seedlings at seven DAS, 2012 crop, were significant for micronutrient interaction and protective treatments $(\mathrm{p}=0.0296)$ (Table 3). When micronutrient 2 was applied with fungicide + insecticide, there was a reduction of approximately $20 \%$ in shoot dry mass and $27 \%$ in root dry mass compared to their association with micronutrient 1 . The association of micronutrient 1 with protective treatments polymer and polymer + fungicide + insecticide reduced the shoot dry mass. The micronutrients used contain manganese, molybdenum, boron, cobalt and zinc. Zinc acts as an enzymatic activator in metabolic routes of lipids and proteins (Prado et al., 2007b), aiding in cell elongation, providing greater growth, increase in the photosynthetic area and consequently increasing the biomass of seedlings (Funguetto et al., 2010). The higher percentage of zinc present in micronutrient 1 may have contributed to these results. Ohse et al. (2012) observed a 31.63\% increase in shoot fresh mass of corn plants submitted to seeds treatment with 0.86 g.kg-1 of $\mathrm{Zn}$. These same authors observed a decreasing in root fresh phytomass with the increase in zinc doses, suggesting a probable toxicity due to the excess of the micronutrient. In the 2013 crop, only the effect of micronutrients $(p=0.0192)$ was observed, with root and shoot dry mass values of the seeds without micronutrients higher than those obtained with their use (Table 4). The effects of the application of micronutrients in seeds are related to the adequate supply of this one by the soil, to the doses and forms of application. In the corn crop, Prado et al. (2007b) obtained an increase in dry matter of root, shoot and total dry matter, when the zinc micronutrient was applied in the form of zinc oxide $(50 \% \mathrm{Zn})$, and a decrease when used in the form of zinc sulfate $(20 \% \mathrm{Zn})$. In sorghum, Yagi et al. (2006) verified that different doses of zinc did not affect the accumulation of dry matter of root and shoot; and in wheat the zinc application in seeds did not influence the shoot dry mass (Orioli Júnior et al., 2008). Likewise, in the 2012 and 2013 crops no significant differences were observed for shoot dry mass of plants at 82 DAS (Tables 5 and 6). Plant height at 41 DAS only showed a significant effect of protective treatments $(p=0.019)$ in the 2013 crop (Table 6), where seeds treated with polymer + fungicide + insecticide showed a plant height $10 \%$ higher compared to untreated seeds.

In the 2012 harvest, there was a significant effect between micronutrient and protective treatments for the number of tillers at 62 DAS $(p=0.017)$ (Table 7). Seeds treated with fungicide + insecticide associated with micronutrient 1 provided the smallest number of tillers. Seeds treated only with micronutrient 2 associated with polymer provided the formation a number of tiller $50 \%$ lower in relation to fungicide + insecticide associated to this micronutrient. In rice, Oliveira et al. (2001) found that the treatment with fungicides allowed the formation of a larger number of tillers in relation to the seeds

Table 4. Shoot dry mass and root dry mass at seven DAS in the wheat culture submitted to seeds treatment with micronutrients and protective treatments (fungicide + insecticide and/or polymer), in 2013.

\begin{tabular}{lcc}
\hline \multicolumn{1}{c}{ Treatment } & $\begin{array}{c}\text { Shoot dry mass } \\
\left(\text { g.plant }^{-1}\right)\end{array}$ & $\begin{array}{c}\text { Root dry mass } \\
(\text { g.plant }\end{array}$ \\
\hline No Micronutrient & $0.325 \mathrm{a}$ & $0.074 \mathrm{a}$ \\
Micro 1 & $0.263 \mathrm{~b}$ & $0.061 \mathrm{~b}$ \\
Micro 2 & $0.252 \mathrm{~b}$ & $0.059 \mathrm{~b}$ \\
\hline \multicolumn{3}{c}{ Protective treatments } \\
\hline NT* & $0.251 \mathrm{a}$ \\
$\mathrm{P}$ & $0.290 \mathrm{a}$ & $0.062 \mathrm{a}$ \\
$\mathrm{F}+\mathrm{I}$ & $0.310 \mathrm{a}$ & $0.065 \mathrm{a}$ \\
$\mathrm{P}+\mathrm{F}+\mathrm{I}$ & $0.270 \mathrm{a}$ & $0.070 \mathrm{a}$ \\
\multicolumn{1}{c}{$\mathrm{CV}(\%)$} & 26.8 & $0.060 \mathrm{a}$ \\
\hline
\end{tabular}

*Untreated (NT), polymer (P), fungicide (F), insecticide (I).

The averages followed by the same letter in the column do not differ among themselves by Scott-Knott test $(\mathrm{p} \leq 0.05)$. 
Table 5. Number of tillers at 41 DAS, plant height at 41 DAS and shoot dry mass at 82 DAS in the wheat culture submitted to seeds treatment with micronutrients and protective treatments (fungicide + insecticide and/or polymer), in 2012 .

\begin{tabular}{|c|c|c|c|}
\hline Treatments & Tillers & $\begin{array}{l}\text { Plant height } \\
(\mathrm{cm})\end{array}$ & $\begin{array}{l}\text { Shoot dry mass } \\
\left.\text { (g.plant }{ }^{-1}\right)\end{array}$ \\
\hline \multicolumn{4}{|c|}{ Micronutrients } \\
\hline No Micronutrient & $1.1 \mathrm{a}$ & $16.0 \mathrm{a}$ & $0.97 \mathrm{a}$ \\
\hline Micro 1 & $0.8 \mathrm{a}$ & $15.5 \mathrm{a}$ & $1.01 \mathrm{a}$ \\
\hline Micro 2 & $1.0 \mathrm{a}$ & $14.7 \mathrm{a}$ & $0.99 \mathrm{a}$ \\
\hline \multicolumn{4}{|c|}{ Protective treatments } \\
\hline $\mathrm{NT}^{*}$ & $0.9 \mathrm{a}$ & $14.6 \mathrm{a}$ & $0.98 \mathrm{a}$ \\
\hline $\mathrm{P}$ & $0.9 \mathrm{a}$ & $16.1 \mathrm{a}$ & $1.03 \mathrm{a}$ \\
\hline $\mathrm{F}+\mathrm{I}$ & $1.0 \mathrm{a}$ & $14.7 \mathrm{a}$ & $0.98 \mathrm{a}$ \\
\hline$\underline{P}+\mathrm{F}+\mathrm{I}$ & $1.2 \mathrm{a}$ & $16.3 \mathrm{a}$ & $0.97 \mathrm{a}$ \\
\hline $\mathrm{CV}(\%)$ & 43.7 & 20.7 & 22.1 \\
\hline
\end{tabular}

*Untreated (NT), polymer (P), fungicide (F), insecticide (I).

The averages followed by the same letter in the column do not differ among themselves by Scott-Knott test $(\mathrm{p} \leq 0.05)$.

that did not receive phytosanitary treatment. Orioli Júnior et al. (2008) observed that the zinc application in seed treatment did not affect the number of tillers of wheat, confirming the results obtained in 2013 harvest, when the number of tillers at 62 DAS did not different between treated seeds, or not, with micronutrients (Table 9).

The average yield of wheat at the 2012 crop $(2.563$ $\mathrm{kg} \mathrm{ha-1}$ ) was higher than the average registered in the state $\left(1.860 \mathrm{~g} \mathrm{ha}^{-1}\right)(\mathrm{CONAB}, 2013)$. There was significant effect to micronutrients $(\mathrm{p}=0.048)$ and protective treatments $(p<0.001)$, but the interaction between these factors was not significant (Table 8). In relation to micronutrients, the addition of micronutrient 1 reduced average grain productivity by $12.1 \%$ compared to treatments without micronutrients. The highest percentage of zinc present in micronutrient 1 did not increase productivity in seeds treated only with this product, and reduced grain yield by $26 \%$ compared to untreated seeds. In white oats culture, Tavares et al. (2013a) obtained an increase of productivity in seeds coated with zinc products. Funguetto et al. (2010) also observed increase in the number of grains per panicle and grain weight per plant from white oats seeds treated with zinc (dose of $0.77 \mathrm{~g} \mathrm{~kg}^{-1}$ of seed) and fungicide $\left(3 \mathrm{~mL} \mathrm{~kg}^{-1}\right)$ associated with polymer CF Clear ${ }^{\circledR}(200$ $\left.\mathrm{mg} \mathrm{kg}^{-1}\right)$ and dye $\left(4 \mathrm{mLkg}^{-1}\right)$. Polymer treated seeds significantly reduced grain yield, reaching a $26 \%$ lower yield compared to the combination polymer with fungicide + insecticide, which showed the highest yield. Balardin et al. (2011) did not find
Table 6. Plant height at 41 DAS and shoot dry mass at 82 DAS in the wheat culture submitted to seeds treatment with micronutrients and protective treatments (fungicide + insecticide and/or polymer), in 2013.

\begin{tabular}{|c|c|c|}
\hline Treatment & $\begin{array}{l}\text { Plant height } \\
(\mathrm{cm})\end{array}$ & $\begin{array}{c}\text { Shoot dry mass } \\
\left(\text { g plant }^{-1}\right)\end{array}$ \\
\hline \multicolumn{3}{|c|}{ Micronutrient } \\
\hline No Micronutrient & $21.0 \mathrm{a}$ & $1.1 \mathrm{a}$ \\
\hline Micro 1 & $20.6 \mathrm{a}$ & $1.1 \mathrm{a}$ \\
\hline Micro 2 & $20.9 \mathrm{a}$ & $1.1 \mathrm{a}$ \\
\hline \multicolumn{3}{|c|}{ Protective treatments } \\
\hline Untreated & $19.7 \mathrm{~b}$ & $1.0 \mathrm{a}$ \\
\hline Polymer & $20.8 \mathrm{a}$ & $1.0 \mathrm{a}$ \\
\hline Fungicide + Insecticide & $21.0 \mathrm{a}$ & $1.2 \mathrm{a}$ \\
\hline Polymer + Fungicide + Insecticide & $21.9 \mathrm{a}$ & $1.1 \mathrm{a}$ \\
\hline CV (\%) & 7.5 & 24.3 \\
\hline
\end{tabular}

The averages followed by the same letter in the column do not differ among themselves by Scott-Knott test $(p \leq 0.05)$.

any impact on seed treatment with different combinations of insecticide and/or fungicide under normal rainfall conditions. However, when exposed to the adverse conditions of water stress, seeds treated with abamectin + thiamethoxam + fludioxonil + mefenoxan + thiabendazole showed grain yield $57.4 \%$ higher than the untreated seeds.

In the 2013 crop, no influence of seed treatment on productivity was observed (Table 9 ). These results agree with Conceição et al. (2014), who did not observed effect of seed treatment with fungicide (Carbendazin + Thiram), insecticide (Imidacloprid + Thiodicarb), micronutrient (Mo 12\%, Co

Table 7. Number of tillers at 62 DAS in the wheat culture submitted to seeds treatment with micronutrients and protective treatments (fungicide + insecticide and/or polymer), in 2012.

\begin{tabular}{|c|c|c|c|}
\hline \multirow{2}{*}{ Protective treatments } & \multicolumn{3}{|c|}{ Micronutrients } \\
\hline & No micronutrient & Micro 1 & Micro 2 \\
\hline $\mathrm{NT}^{*}$ & $1.1 \mathrm{Aa}$ & $1.2 \mathrm{Aa}$ & $0.7 \mathrm{Ab}$ \\
\hline $\mathrm{P}$ & $0.8 \mathrm{Aa}$ & $0.8 \mathrm{Aa}$ & $0.7 \mathrm{Ab}$ \\
\hline $\mathrm{F}+\mathrm{I}$ & $1.0 \mathrm{Aa}$ & $0.5 \mathrm{Ba}$ & $1.4 \mathrm{Aa}$ \\
\hline $\mathrm{P}+\mathrm{F}+\mathrm{I}$ & $0.8 \mathrm{Aa}$ & $0.9 \mathrm{Aa}$ & $1.3 \mathrm{Aa}$ \\
\hline CV (\%) & \multicolumn{3}{|c|}{40.3} \\
\hline
\end{tabular}

*Untreated (NT), polymer (P), fungicide (F), insecticide (I).

The averages followed by the same letter, uppercase in the line and lowercase in the column, do not differ among themselves by Scott-Knott test $(\mathrm{p} \leq 0.05)$. 
Table 8. Grain productivity and hectoliter weight in the wheat culture submitted to seeds treatment with micronutrients and protective treatments (fungicide + insecticide and/or polymer), in 2012.

\begin{tabular}{|c|c|c|c|c|c|c|c|c|}
\hline \multirow{3}{*}{$\mathrm{PT}^{*}$} & \multicolumn{4}{|c|}{ Productivity (kg.ha- $\left.{ }^{-1}\right)$} & \multicolumn{4}{|c|}{ Hectoliter weigth $\left(\mathrm{kg} . \mathrm{hl}^{-1}\right)$} \\
\hline & \multicolumn{8}{|c|}{ Micronutrients } \\
\hline & $\mathrm{N} / \mathrm{M}$ & M1 & M2 & Average & $\mathrm{N} / \mathrm{M}$ & M1 & M2 & Average \\
\hline NT & 3066.4 & 2273 & 2717.8 & $2685.7 \mathrm{a}$ & $81.0 \mathrm{Aa}$ & $80.3 \mathrm{Aa}$ & $79.5 \mathrm{Aa}$ & 80.3 \\
\hline $\mathrm{P}$ & 1919.8 & 2309.8 & 2211.8 & $2147.1 \mathrm{~b}$ & $79.4 \mathrm{Ba}$ & $78.5 \mathrm{Bb}$ & $81.4 \mathrm{Aa}$ & 79.7 \\
\hline $\mathrm{F}+\mathrm{I}$ & 2676.1 & 2389.6 & 2474.6 & $2513.4 \mathrm{a}$ & $79.3 \mathrm{Aa}$ & $80.2 \mathrm{Aa}$ & $80.4 \mathrm{Aa}$ & 80 \\
\hline $\mathrm{P}+\mathrm{F}+\mathrm{I}$ & 3317.9 & 2675.3 & 2720.3 & $2904.5 \mathrm{a}$ & $78.9 \mathrm{Aa}$ & $81.0 \mathrm{Aa}$ & $79.4 \mathrm{Aa}$ & 79.8 \\
\hline Average & $2745.1 \mathrm{~A}$ & $2411.9 \mathrm{~B}$ & $2531.2 \mathrm{~B}$ & 2562.7 & 79.7 & 80 & 80.2 & 79.9 \\
\hline
\end{tabular}

*Protective treatments (PT), Untreated (NT), polymer (P), fungicide (F), insecticide (I) no micronutrients (N/M), micronutrients (M).

The averages followed by the same letter, uppercase in the line and lowercase in the column, do not differ among themselves by Scott-Knott test ( $\mathrm{p} \leq 0.05)$.

Table 9. Number of tillers, grain productivity and hectoliter weight in the wheat culture submitted to seeds treatment with micronutrients and protective treatments (fungicide + insecticide and/or polymer), in 2013.

\begin{tabular}{|c|c|c|c|c|}
\hline Treatment & $\begin{array}{c}\text { Tillers } \\
41 \text { DAS }\end{array}$ & $\begin{array}{c}\text { Tillers } \\
62 \text { DAS } \\
\end{array}$ & $\begin{array}{l}\text { Productivity } \\
\left(\text { kg.ha }^{-1}\right)\end{array}$ & $\begin{array}{c}\text { Hectoliter weight } \\
\left(\mathrm{kg} \cdot \mathrm{hl}^{-1}\right)\end{array}$ \\
\hline No Micronutrient & $1.9 \mathrm{a}$ & $2.9 \mathrm{a}$ & $3383.1 \mathrm{a}$ & $68.4 \mathrm{a}$ \\
\hline Micro 1 & $1.3 \mathrm{~b}$ & $2.8 \mathrm{a}$ & $3370.6 \mathrm{a}$ & $68.8 \mathrm{a}$ \\
\hline Micro 2 & $1.1 \mathrm{~b}$ & $2.4 \mathrm{a}$ & $3368.8 \mathrm{a}$ & $68.2 \mathrm{a}$ \\
\hline \multicolumn{5}{|c|}{ Protective treatments } \\
\hline Untreated & $1.4 \mathrm{a}$ & $2.9 \mathrm{a}$ & $3385.3 \mathrm{a}$ & $68.0 \mathrm{a}$ \\
\hline Polymer & $1.6 \mathrm{a}$ & $3.0 \mathrm{a}$ & $3453.1 \mathrm{a}$ & $68.3 \mathrm{a}$ \\
\hline Fungicide + Insecticide & $1.7 \mathrm{a}$ & $2.6 \mathrm{a}$ & $3318.3 \mathrm{a}$ & $69.2 \mathrm{a}$ \\
\hline Polymer + Fungicide + Insecticide & $1.1 \mathrm{a}$ & $2.4 \mathrm{a}$ & $3340.0 \mathrm{a}$ & $68.5 \mathrm{a}$ \\
\hline CV (\%) & 47.9 & 27.9 & 10.3 & 2.5 \\
\hline
\end{tabular}

The averages followed by the same letter in the column do not differ among themselves by Scott-Knott test $(\mathrm{p} \leq 0.05)$.

$1 \%$ and $\mathrm{B} 1 \%$ ) and polymer in soybean grain productivity, although treatment has provided higher protection for the seeds and seedlings on field. Ávila et al. (2006) also do not report effect of corn seed treatment with fungicide and insecticide, and that received micronutrients $(20.0 \% \mathrm{Zn}, 3.0 \%$ $\mathrm{B}, 1.0 \% \mathrm{Mg}$ and $1.0 \% \mathrm{Mo}$ ) at the time of sowing.

Results for hectoliter weight in the 2012 crop show the interaction between protective treatments and micronutrients $(\mathrm{p}=0.0142)$ (Table 8$)$. The combination of micronutrient 1 with polymer reduced the weight of the hectoliter, but did not differ from the seeds treated only with polymer. When the polymer was added to the micronutrient 2 , the highest value of the hectoliter weight was obtained. According to the official classification standard for grain or meal yield (Brasil, 2010), the average weight of the hectoliter obtained in the 2012 harvest was higher than the minimum established for type 1 wheat.

In the 2013 crop, there was no effect of seed treatment (Table 9) on hectoliter weight. The value of hectoliter weight was less than the weight for classification "out of type" $(<72)$. The rainfall precipitation has been indicated as the main factor that reduces the hectoliter weight, either negatively by the water excess in the period of physiological maturation and/or by the water deficit in the other phases of the wheat crop (Guarienti et al., 2005). Therefore, grain quality in the 2013 crop may have been affected by adverse climatic conditions in the maturation and harvesting phase, when more rainfall occurred in the wheat crop.

\section{Conclusions}

Treatment of seeds with micronutrients ( $1 \% \mathrm{Mn}, 0.1 \%$ Mo, $10 \% \mathrm{Zn}$ and $0.3 \% \mathrm{~B}, 0.3 \% \mathrm{Co} ; 3 \% \mathrm{Zn}$ ), polymer (Color seed He), fungicide (Vitavax® Thiram 200 SC) + insecticide (Cruiser ${ }^{\circledR} 350 \mathrm{FS}$ ) and its combinations do not reduce plant emergence and may increase seedling stand.

The use of seed protection products does not increase the wheat grain yield. 


\section{Acknowledgments}

We would like to thank the Foundation for Research Support of the State of Rio Grande do Sul - FAPERGS, for granting the scholarship to the first author.

\section{References}

ARNHOLD, E. Package in the R environment for analysis of variance and complementary analyses. Brazilian Journal of Veterinary Research and Animal Science, v.50, n.6, p.488-492, 2013. http:// dx.doi.org/10.11606/issn.1678-4456.v50i6p488-492

AVELAR, S.A.G.; BAUDET, L.; OLIVEIRA, S.; LUDWIG, M.P.; CRIZEL, R.L.; RIGO, G.A. Tratamento e recobrimento de sementes de soja com polímeros líquido e em pó. Interciencia, v.40, n.2, p.133-137, 2015. http://www.redalyc.org/pdf/339/33934014011.pdf

AVELAR, S.A.G.; SOUSA, F.V.; FISS, G.; BAUDET, L.; PESKE, S.T. The use of film coating on the performance of treated corn seed. Revista Brasileira de Sementes, v.34, n.2, p.186-192, 2012. http:// dx.doi.org/10.1590/S0101-31222012000200001

ÁVILA, M.R.; BRACCINI, A.L.; SCAPIM, C.A.; MARTORELLI, D.T.; ALBRECHT, L.P.; FACIOLLI, F.S. Qualidade fisiológica e produtividade das sementes de milho tratadas com micronutrientes e cultivadas no período de safrinha. Acta Scientiarum Agronomy, v.28, n.4, p.535-543, 2006. http://dx.doi.org/10.4025/actasciagron. v28i4.927

BALARDIN, R.S.; SILVA, F.D.L.; DEBONA, D.; CORTE, G.D.; FAVERA, D.D.; TORMEN, N.R. Tratamento de sementes com fungicidas e inseticidas como redutores dos efeitos do estresse hídrico em plantas de soja. Ciência Rural, v.41, n.7, p.1120-1126, 2011. http://dx.doi.org/10.1590/S0103-84782011000700002

BAYS, R.; BAUDET, L.; HENNING, A.A.; LUCCA FILHO, O. Recobrimento de sementes de soja com micronutrientes, fungicida e polímero. Revista Brasileira de Sementes, v.29, n.2, p.60-67, 2007. http://dx.doi.org/10.1590/S0101-31222007000200009

BRASIL. Ministério da Agricultura, Pecuária e Abastecimento. Instrução Normativa $n^{\circ} .38$, de 30 de novembro de 2010. Regulamento técnico do trigo. Diário Oficial da República Federativa do Brasil, Brasília, DF, Seção 1, p.2.

BRZEZINSKI, C.R.; HENNING, A.A.; ABATI, J.; HENNING, F.A.; FRANÇA-NETO, J.B.; KRZYZANOWSKI, F.C.; ZUCARELI, C. Seeds treatment times in the establishment and yield performance of soybean crops. Journal of Seed Science, v.37, n.2, p.147-153, 2015. http://dx.doi.org/10.1590/2317-1545v37n2148363

CASTRO, G.S.A.; BOGIANI, J.C.; SILVA, M.G.; GAZOLA, E.; ROSOLEM, C.A. Tratamento de sementes de soja com inseticidas e um bioestimulante. Pesquisa Agropecuária Brasileira, v.43, n.10, p.1311-1318, 2008. http://www.scielo.br/pdf/pab/v43n10/08.pdf

Comissão de Química e Fertilidade do Solo RS/SC - CQFS-RS/ SC. Manual de adubação e de calagem para o Estado do Rio Grande do Sul e Santa Catarina. Porto Alegre: UFRGS, 2004. 400p.
CONAB. Companhia Nacional de Abastecimento. Acompanhamento de safra brasileira de grãos. Quarto levantamento, Brasília: Conab, 2013. http://www.conab.gov.br/OlalaCMS/uploads/ arquivos/14_01_10_15_07_19_boletim_graos_janeiro_2014.pdf

CONCEIÇÃO, G.M.; BARBIERI, A.P.P.; LÚCIO, A.D; MARTIN, T.N.; MERTZ, L.M.; MATTIONI, N.M.; LORENTZ, L.H. Desempenho de plântulas e produtividade de soja submetida a diferentes tratamentos químicos nas sementes. Bioscience Journal, v.30, n.6, p.1711-1720, 2014. http://www.seer.ufu.br/index.php/ biosciencejournal/article/view/22024/15608

DAN, L.G.M.; DAN, H.A.; PICCININ, G.G.; RICCI, T.T.; ORTIZ, A.H.T. Tratamento de sementes com inseticida e a qualidade fisiológica de sementes de soja. Revista Caatinga, v.25, n.1, p.45-51, 2012. https://periodicos.ufersa.edu.br/index.php/ caatinga/article/view/2073/pdf

EMBRAPA. Empresa Brasileira de Pesquisa Agropecuária. Informações técnicas para trigo e triticale safra 2012. V Reunião da Comissão Brasileira de Pesquisa de Trigo e Triticale. Dourados, MS: Embrapa Agropecuária Oeste, 2011. 204p. http://www.cnpt. embrapa.br/culturas/trigo/informacoes_tecnicas_trigo_triticale_ safra_2012.pdf

FRANCESCHI, L.; BENIN, G.; GUARIENTI, E.; MARCHIORO, V.S.; MARTIN, T.N. Fatores pré-colheita que afetam a qualidade tecnológica de trigo. Ciência Rural, v.39, n.5, p.1624-1631, 2009. http://www.scielo.br/pdf/cr/v39n5/a166cr890.pdf

FUNGUETTO, C.I.; PINTO, J.F.; BAUDET, L.; PESKE, S.T. Desempenho de sementes de arroz irrigado recobertas com zinco. Revista Brasileira de Sementes, v.32, n.2, p.117-123, 2010. http:// www.scielo.br/pdf/rbs/v32n2/v32n2a14.pdf

GUARIENTI, E.M.; CIACCO, C.F.; CUNHA, G.R.; DEL DUCA, L.J.A.; CAMARGO, C.M.O. Efeitos da precipitação pluvial, da umidade relativa do ar e de excesso e déficit hídrico do solo no peso do hectolitro, no peso de mil grãos e no rendimento de grãos de trigo. Ciência e Tecnologia de Alimentos, v.25, n.3, p.412-418, 2005. http://www.scielo.br/pdf/cta/v25n3/27004.pdf

GARCIA JÚNIOR, D.; VECHIATO, M.H.; MENTEN, J.O.M. Efeito de fungicidas no controle de Fusarium graminearum, germinação, emergência e altura de plântulas em sementes de trigo. Summa Phytopathologica, v.34, n.3, p.280-283, 2008. http:// dx.doi.org/10.1590/S0100-54052008000300018

IAPAR. Instituto Agronômico do Paraná. Informações técnicas para trigo e triticale safra 2013. In: VI Reunião da Comissão Brasileira de Pesquisa de Trigo e Triticale. Londrina,PR: Instituto Agronômico do Paraná, 2012. 220p. http://www.iapar.br/arquivos/File/zip_pdf/ TrigoeTriticale 2013.pdf

MERTZ, L.M.; HENNING, F.A.; ZIMMER, P.D. Bioprotetores e fungicidas químicos no tratamento de sementes de soja. Ciência Rural, v.39, n.1, p.13-18, 2009. http://www.scielo.br/scielo. php?script=sci_arttext\&pid=S0103-84782009000100003

OHSE, O.; CUBIS, J.G.; REZENDE, B.L.A.; CORTEZ, M.G.; OTTO, R.F. Vigor e viabilidade de sementes de trigo tratadas com zinco. Revista Biotemas, v.25, n.4, p.49-58, 2012. https:// periodicos.ufsc.br/index.php/biotemas/article/view/2175$7925.2012 \mathrm{v} 25 \mathrm{n} 4 \mathrm{p} 49 / 23226$ 
OLIVEIRA, W.F.; PIMENTEL, D.M.; ALBERNAZ, R.S.; MACHADO, L.A.; BATISTA, R.G.; RAMALHO, V. Efeito de produtos fitossanitários no tratamento de sementes de arroz (Oryza sativa L.) visando ao controle de Pyricularia grisea. Pesquisa Agropecuária Tropical, v.31, n.1, p.4346, 2001. https://www.revistas.ufg.br/pat/article/view/2525

ORIOLI JÚNIOR, V.; PRADO, R.M.; LEONEL, C.L.; CAZETTA, D.A.; SILVEIRA, C.M.; QUEIROZ, R.J.B.; BASTOS, J.C.H.A.G. Modos de aplicação de zinco na nutrição e na produção de massa seca de plantas de trigo. Revista de la Ciencia del Suelo y Nutrición Vegetal, v.8, n.1, p.28-36, 2008. http://www.scielo.cl/scielo. php?script=sci_arttext\&pid=S0718-27912008000100003

PEREIRA, C.E.; OLIVEIRA, J.A.; EVANGELISTA, J.R.E. Qualidade fisiológica de sementes de milho tratadas associadas a polímeros durante o armazenamento. Ciência e Agrotecnologia, v.29, n.6, p.1201-1208, 2005. http://www.scielo.br/scielo. php?script $=$ sci_arttext\&pid $=$ S1413-70542005000600014

PICININI, E.C.; FERNANDES, J.M.C. Efeito do tratamento de sementes com fungicidas sobre o controle de doenças na parte aérea do trigo. Fitopatologia Brasileira, v.28, n.5, p.515-520, 2003. http:// dx.doi.org/10.1590/S0100-41582003000500008

PRADO, R.M.; FRADE JUNIOR, E.F.; MOUTA, E.R.; JOÃO, A.C.G.S.; COSTA, R.S.S. Crescimento inicial e estado nutricional do trigo submetido à aplicação de zinco via semente. Revista de la Ciência del Suelo y Nutrición Vegetal, v.7, n.2, p.22-31, 2007a. http://www.scielo.cl/scielo. php?script=sci_arttext\&pid= S0718$27912007000200003 \& \operatorname{lng}=$ pt\&nrm $=$ iso\&tlng $=$ pt
PRADO, R.M.; NATALE, W.; MOURO, M.C. Fontes de zinco aplicado via semente na nutrição e crescimento inicial do milho cv. Fort. Bioscience Journal, v.23, n.2, p.16-24, 2007b. http://www. seer.ufu.br/index.php/biosciencejournal/article/view/6375/4117

TAVARES, L.C.; BRUNES, A.P.; TUNES, L.M.; GADOTTI, G.I.; BARROS, A.C.S.A.; VILLELA, F.A. The yield and physiological quality of oat seeds subjected to cover with zinc. Acta Scientiarum Agronomy, v.35, n.3, p.357-361, 2013a. http://www.scielo.br/pdf/ asagr/v35n3/v35n3 a12.pdf

TAVARES, L.C.; RUFINO, C.A.; BRUNES, A.P.; FRIEDRICH, F.F.; BARROS, A.C.S.A.; VILLELA, F.A. Physiological performance of wheat seeds coated with micronutrients. Journal of Seed Science, v.35, n.1, p.28-34, 2013b. http://www.scielo.br/pdf/jss/v35n1/04.pdf

TUNES, L.M.; PEDROSO, D.C.; TAVARES, L.C.; BARBIERI, A.P.P.; BARROS, A.C.S.A.; MUNIZ, M.F.B. Tratamento de sementes de trigo com zinco: armazenabilidade, componentes do rendimento e teor do elemento nas sementes. Ciência Rural, v.42, n.7, p.1141-1146, 2012. http://www.scielo.br/scielo.php?script=sci arttext\&pid=S0103-84782012000700001

YAGI, R. SIMILI, F.F.; ARAÚJO, J.C.; PRADO, R.M.; SANCHEZ, S.V.; RIBEIRO, C.E.R.; BARRETTO, V.C.M. Aplicação de zinco via sementes e seu efeito na germinação, nutrição e desenvolvimento inicial do sorgo. Pesquisa Agropecuária Brasileira, v.41, n.4, p.655660, 2006. http://www.scielo.br/pdf/pab/v41n4/29813.pdf 